Artigo recebido em

20/03/2014

Aprovado em

$30 / 04 / 2014$

LEANI BUDDE

Universidade Federal de Santa Catarina leani8@yahoo.com.br

Graduada em Psicologia pela Universidade do

Vale do Itajaí (1994)

e em Jornalismo pela

Universidade Federal de

Santa Catarina (1985).

Mestrado em Literatura

(2007) e Doutorado

Interdisciplinar em

Ciências Humanas (2012),

ambos pela Universidade

Federal de Santa Catarina. Bolsista Capes.

ALEXANDRE FERNANDEZ VAZ

Universidade Federal de Santa Catarina alexfvaz@uol.com.br

Doutor em Ciências

Humanas e Sociais

(Leibniz Universität

Hannover, Alemanha).

Professor dos Programas

de Pós-graduação em

Educação e Interdisciplinar

em Ciências Humanas/

UFSC, Coordenador

do Núcleo de Estudos

e Pesquisas Educação e

Sociedade Contemporânea

(UFSC/CNPq).

Pesquisador CNPq.
Estudos em Jornalismo e Mídia

Vol. $11 \mathrm{~N}^{\circ} 1$

Janeiro a Junho de 2014

ISSNe 1984-6924

\section{Jornalismo e ditadura em Florianópolis: sobre o jornal $O$ Estado}

\section{Leani Budde e Alexandre Fernandez Vaz}

\section{Resumo}

O regime militar no Brasil teve entre suas características o domínio ideológico e o controle social, exercido através dos meios de comunicação. Com o apoio explícito de jornais, rádios e TVs, ou por meio da censura às informações divulgadas, o regime se consolidou e permitiu o fortalecimento de monopólios na área de comunicação. Em Florianópolis, apesar do apoio inicial ao regime, o jornal O ESTADO passa por reformulações gráficas e editoriais justamente no período de maior recrudescimento da ditadura, atingindo então, contraditoramente, o período mais expressivo em termos jornalísticos. Deixa de ter a preferência como porta-voz dos militares, que optam pela RBS - Rede Brasil Sul de Comunicações, do Rio Grande do Sul, ao conceder ao grupo a outorga da concessão de TV, que também era disputada por $\mathrm{O}$ ESTADO.

\section{Palavras-chave}

Ditadura militar, monopólio comunicacional, jornalismo impresso.

\begin{abstract}
The military government in Brazil was characterized by ideological domination and social control, exercised through the media. Through explicit support of newspapers, radio and TV, or through the censure of information disseminated, the government was consolidated and enabled the strengthening of monopolies in the communication area. In Florianopolis, despite the initial support to the government plan, the newspaper O ESTADO is being reformulated graphic and editorial precisely at a time of resurgence of dictatorship, reaching then, in other hand, the most significant period in journalistic terms. Break off to be preferred as the representative of the military, who opting for RBS - Network Communications Southern Brazil, from Rio Grande do Sul, and give to the group the Concession TV, which was also disputed by O ESTADO.
\end{abstract}

Keywords

Military oppression, communication monopolies, printed journalism. 
1- O presente traba-

lho contou com apoio financeiro da CAPES (Bolsa de doutorado) e apresenta resultados parciais dos projetos Teoria Crítica, Racionalidades e Educação

(IV), financiado pelo

CNPq.

2 Período da história política iniciado com o golpe militar de 31 de março de 1964, que resultou no afastamento do Presidente da República, João Goulart, assumindo o governo federal o Marechal Castelo Branco. O regime militar teve ao todo cinco presidentes e uma junta governativa, estendendo-se do ano de 1964 até 1985 , com a eleição do civil Tancredo Neves. O regime pôs em prática vários Atos Institucionais, culminando com o Al-5 de 1968, que determinou a suspensão da Constituição de 1946, a dissolução do Congresso Brasileiro, e a supressão de liberdades individuais. Ao extinguir os partidos políticos estabeleceu o bipartidarismo, através da Arena - Aliança de Renovação Nacional, que absorveu os partidos conservadores como a UDN e PSD, e o MDB - Movimento Democrático Brasileiro, que aglutinava os oposicionistas. Grupos políticos mais à esquerda tentaram combater $o$ regime ditatorial por meio de guerilha urbana e rural e foram violentamente reprimidos, com prisão, tortura e assassinato de seus militantes.

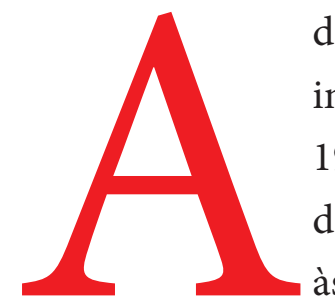

ditadura cívico-militar instalada no Brasil de 1964 a $1985^{2}$ teve apoio de empresários ligados às comunicações em todo país. O jornal O ESTADO, de Florianópolis, capital de Santa Catarina, era um dos veículos que explicitamente defendia os interesses da ARENA Aliança Renovadora Nacional, sigla que dava sustentação ao regime. Com a vinculação desde 1945 ao antigo PSD $^{3}$ - Partido Social Democrata, juntouse à agremiação política adversária de décadas, a UDN - União Democrática Nacional, na defesa da ARENA e do governo militar.

Por contraditório que pareça, nesse período $\mathrm{O}$ ESTADO atinge sua fase mais significativa na qualidade de seu jornalismo, ao adotar formato gráfico moderno e profissionalizar sua redação a partir de 1972, no auge do regime de exceção. A modernização gráfica do impresso, frequentemente exaltada em edições comemorativas de seu aniversário, junto com a formação de equipe jornalística experiente em informar e não apenas defender um partido político, pressupunha um direcionamento do veículo no sentido da democratização, ou pelo menos, da pluralidade do foco noticioso. Não deixa de ser algo peculiar no momento em que começava a se fomentar no país uma tendência nas principais capitais brasileiras, parte da estratégia política dominante daquele momento em que confluíam os interesses do regime militar e dos empresários da área de comunicação. O governo precisava interiorizar a comunicação no Brasil para consolidar o domínio ideológico e os empresários visavam aumentar seus ganhos ampliando seu alcance junto ao público e tendo maior número de veículos sob seu controle. Ortiz (1991), entre outros autores, demonstra a estreita ligação entre os propósitos da ditadura militar do Brasil e o fortalecimento de monopólios comunicacionais, especialmente o da Rede Globo e suas afiliadas, para a ocupação ideológica e a interiorização do país. Em Florianópolis, emissoras de rádio e jornais impressos também colaboraram na implementação do ideário autoritário (MAY, 1998; PERTILE, 2003).

O presente artigo visa demonstrar a trajetória de O ESTADO nas décadas de 1970 e 1980, consideradas o período áureo do jornal, já que a partir dessa transição para um novo jornalismo, começou a ser visto como um impresso digno de credibilidade em sua busca da neutralidade/imparcialidade jornalística, algo que, paradoxalmente, acontece no momento em que a liberdade de expressão era cerceada em todo território nacional.

Talvez essa contradição indique que apesar de cumprir seu papel e apoiar o regime, não foi o veículo de comunicação de Florianópolis preferido pelo governo ditatorial, que acabou apostando no conglomerado RBS - Rede Brasil Sul de Comunicações como principal aliado de seus propósitos. A chegada do grupo do Rio Grande do Sul, em 1979, ajuda a entender a progressiva decadência de $\mathrm{O}$ ESTADO a partir dos anos 1990.

\section{Um jornal político e partidário}

Fundado por comerciantes em 1915, O ESTADO sempre esteve atrelado a interesses político-partidários. $\mathrm{O}$ 
primeiro líder político a controlar o periódico foi Victor Konder, Ministro do governo Washington Luz, que se exilou em Portugal após a chegada ao poder, em 1930, de Getulio Vargas, a quem o jornal combatia na ocasião. Em 1945 foi comprado pelo político Aderbal Ramos da Silva (o ARS), principal proprietário

\section{Fundado por}

\section{comerciantes}

\section{en 1915, o jornal}

sempre esteve

atrelado a

\section{interesses}

\section{político-partidários}

do jornal ao longo de toda sua existência, deputado e depois governador, passando então a defender as bandeiras do antigo PSD.

O que ocorria em Santa Catarina não é diferente do que está presente na história do jornalismo como um todo, conforme demonstrou Rüdiger (2010 p. 220), segundo o qual "O jornalismo, ninguém negará, se desenvolveu a reboque do curso seguido pela vida política. As folhas de vários tipos foram muito tempo órgãos de partidos." Em Santa Catarina, porém, a mudança no perfil chega mais tardiamente e o período em que cada partido tinha seu próprio jornal se estende ao longo dos anos, sendo o da UDN - União Democrática Nacional (família Konder Bornhausen) A Gazeta, extinto nos anos 1960. Como as duas siglas estavam reunidas sob a agremiação ARENA, bastava um jornal na pequena capital, e O ESTADO havia se comprometido a cumprir seu papel (MAY, 1998).

\section{O político Aderbal Ramos da Silva comanda nos bastidores do jornal}

As preferências políticas do exgovernador e sua influência sobre a trajetória do jornal ficam mais evidentes quando se analisa sua ligação com o regime e os desdobramentos políticos daí resultantes. Com a dissolução dos partidos pela ditadura cívico-militar e a instalação do bipartidarismo, a UDN (Konder Bornhausen) e parte do PSD (Ramos) se aglutinam em torno da ARENA. Ou seja, nesse período, O ESTADO que havia sido comprado por Aderbal para se contrapor aos Konder Bornhausen, passou também a apoiá-los, já que agora estavam todos juntos sob a mesma sigla partidária. Essa fusão suspendeu as disputas políticas entre os dois grupos conservadores através dos meios de comunicação, o que possivelmente contribuiu para a extinção do jornal A Gazeta, ligado à UDN. O ESTADO apoiou o golpe de 1964 e a campanha financeira para "reconstrução nacional". Conforme May (1998, p. 136), "de acordo com o jornal O ESTADO, ficou estabelecido em reunião que a imprensa escrita e falada daria a ela seu apoio, fazendo 'slogans', 'jingles 'e outras modalidades de propaganda." Como se observa, o apoio foi explicitamente divulgado, não se travestindo apenas em conteúdo editorial político e ideológico de defesa do regime. No final dos anos 1960, Colombo Salles foi governador respaldado pela corrente pessedista dos
3- Embora a sigla $P S D$ recriada em 2011 tenha caráter liberal-conservador, como o antigo PSD, este apoiava nos anos 1940 o PTB de Getulio Vargas, formando o bloco pró-getulista da política brasileira, em oposição à União

Democrática

Nacional (UDN), antigetulista. O PSD do século passado elegeu Juscelino Kubitscheck para Presidente da República, em 1955, e foi extinto pela ditadura

dez anos depois, quando parte de seus integrantes integrouse ao MDB-Movimento Democrático Brasileiro (oposição) e outros juntaram-se à Arena. 
Ramos, mas passou a sofrer oposição da imprensa local ao declarar "guerra às oligarquias". Considerado um gestor moderno à época, a ressalva a seu nome demonstra as divisões dentro da agremiação que defendia o governo autoritário. Aderbal deixa de apoiá-lo e Colombo Salles perde a sucessão para Antonio Carlos Konder Reis, escolhido pelos militares, em 1972.

Já sem cargo público, Aderbal dizia em 1977 que O ESTADO não poderia mais ser porta-voz de partido, porém, apoiava, na medida do possível, a ARENA. Mas a relação era conturbada, com episódios como o de 23 de novembro de 1978, quando o jornal abre espaço na capa para anunciar resumo do editorial "Gesto que amesquinha". Mencionava o "boicote do governador Konder Reis ao jornal, suprimindo qualquer matéria paga de O ESTADO [...] a partir daquela edição todas as notas, reportagens, artigos e informações tratavam o governador de SC de 'Antonio C. K. Reis '." (PEREIRA, 1992, p. 92). O sobrenome histórico e

4- Refere-se ao sistema analógico de transmissão do sinal da TV, divulgada através de rádio transmissões em canais designados na frequência entre 54 e $890 \mathrm{MHz}$. É um sistema de curto alcance, permite aos telespectadores sintonizar canais com abrangência local/regional. Neste formato, a programação de rede nacional é difundida por retransmissores locais. É diferente do sistema via satélite, em que o próprio telespectador sintoniza diretamente os canais nacionais e internacionais. representante da oligarquia Konder era omitido propositalmente pelo jornal, como forma de desprestigiar e sutilmente confrontar o governador. Ex-dirigentes contam mais detalhes dessa ruptura entre o jornal e o governador daquele período:

Com suas manias, achava que o jornal, sendo do PSD, ainda não o tratava como se fosse, estivessem todos juntos. Na verdade, fazíamos jornalismo, ele queria só favor, algo chapa branca. A ponto do Konder Reis cortar verba da publicidade do governo, essa coisa toda, houve uma ruptura, do estado com O ESTADO, a ponto do jornal só chamá-lo de AK Reis. Pra deixá-lo bem nervoso mesmo, ele ficava furioso, chamando-o de AK Reis. [...] Mas o jornal não se rendeu, e sempre foi assim.
(SCHLINDWEIN, depoimento, 2011).

Tivemos problemas, porque todos os jornais dependem muito de verba pública. E nós, foi num governo, hoje até é meu amigo, mas no governo Antonio Konder Reis nós ficamos praticamente quatro anos sem receber um tostão do governo, por causa de nossa posição de independência. Talvez burrice também, intransigência, talvez hoje, não sei se faria isso, mas faria sim. É porque ele queria mandar no jornal e tal, então eu: "Então, o Sr, compra um jornal pra fazer isso, quer editar um jornal, o $\mathrm{Sr}$ compre um, que aqui nesse não". Aí ele ficou uma fera. (COMELLI, depoimento, 2011).

Essa crise na relação com o governo estadual tivera início um ano antes, quando da concessão, pelo governo federal, para Florianópolis, do segundo canal de televisão VHF - Very Hight Frequency ${ }^{4}$. A disputa pelo novo canal seria determinante pois todos os pretendentes à concessão já sabiam da força que a televisão passara a ter entre os meios de comunicação de massa. Valente (2005) relata em detalhes o processo de escolha dos concessionários do canal, em que Comelli esperava ser vitorioso:

Sirotsky propõe sociedade a Comelli e ao ex-governador Aderbal Ramos da Silva. A minuta do contrato chega a ser redigida. Mas a pressão contra essa aliança com "os estrangeiros" cresce. Imaginavam os opositores da sociedade, que numa disputa com um pretendente de outro estado, o governador tomaria partido dos locais. Comelli e Aderbal recuam e Sirotsky decide entrar na disputa sem sócios. Em 1977 a TV Catarinense é outorgada à RBS (Rede Brasil Sul), de Sirotsky, com as bênçãos de Antônio Carlos Konder Reis. A televisão entra no ar em 
1979 retransmitindo a programação da Globo, que anteriormente era exclusividade da TV Coligadas. [...] a ganhadora chega ao estado com o poderosíssimo trunfo que é a Rede Globo e seu quase monopólio de faturamento comercial. Assim como a chegada do off-set e das novas práticas profissionais foi importante para os jornalistas e para o jornalismo, a disputa pelo segundo canal de TV em Florianópolis foi decisiva para as empresas. (VALENTE, C. In: BALDESSAR \& CRISTOFOLETTI, 2005, p. 80).

Como se pode observar, a disputa pela emissora de TV deixaria sequelas políticas e consequências no panorama concorrencial, já que a chegada da RBS contribuiu para as mudanças na imprensa local e mesmo na cidade de Florianópolis. Uma das consequências da instalação da RBS foi a intensificação da integração estadual por meio da comunicação, já que no mesmo período o governo federal ampliava a rede de telecomunicações no estado, o que ajudou na formação e implantação do sistema em rede de emissoras de TV. Era a execução em Santa Catarina da parceria entre o governo cívico-militar e os conglomerados de comunicação.

ARS, embora dono dos principais veículos de comunicação à época, raramente concedia entrevistas, mas "nos fins de tarde, com frequência 'batia ponto ' no estacionamento de O ESTADO, onde mantinha conversas com o editorchefe Luiz Henrique Tancredo, redator da 'Informação Geral', a coluna editorial ${ }^{5}$ do jornal." (PEREIRA, 2011, p. 21).

Integrantes da família Ramos dirigiram o jornal depois de Barreiros Filho ocupar o cargo como um dos primeiros homens de confiança de ARS. Primo de Aderbal, Rubens de Arruda Ramos atuou no impresso até 1965, e assinava sua principal coluna política daqueles anos, sob o pseudônimo de Guilherme Tal. Era pai do colunista Paulo da Costa Ramos (PCR) ${ }^{6}$ e do cronista Sérgio da Costa Ramos, este detido por alguns dias durante o período ditatorial devido a uma crônica em que supostamente fazia críticas ao general Artur da Costa e Silva, que então chefiava o país. Rubens de Arruda Ramos foi substituído por Domingos Fernandes de Aquino e, aos poucos, as notícias foram ocupando o lugar dos artigos de opinião.

Até o início dos anos 1970 o jornal mantinha o propósito de dirigir a opinião pública por meio de um discurso de conotações claras, omitindo opiniões contrárias ou divergências políticas e sociais. Aos poucos, porém, foi também se deslocando da esfera predominantemente política para incorporar outros temas de interesse da população. As mudanças foram implementadas depois que assumiu a direção do jornal o genro de ARS, José Matusalém Comelli ${ }^{7}$, que ficaria à frente do periódico até sua falência. $\mathrm{O}$ diretor presidente admite a ligação partidária, mas ressalva as mudanças que começaram a ocorrer a partir de sua gestão:

Eu comecei a mudar até no visual político, era um jornal do partido, PSD, ninguém escondia isso. Até numa ocasião um queixoso desse, saiu alguma coisa que não tinha gostado e perguntou pra mim: "Afinal esse jornal é nosso ou não é?", "Nosso o que?" "Do PSD" "É mais ou menos, é dos amigos". Nós quebramos alguns tabus, tinha notícia que não se dava e tal, e passamos a trazer reivindicações do povo, da coletividade. $\mathrm{O}$ ônibus quebrava, atrasava, e eram tudo coisas de correligionários... Eram pessoas que antes eram inatingíveis, coisas que eram ignoradas. (COMELLI, depoimento, 2011).
5- $O$ editorial é a parte do jornal que reflete a posição oficial da direção sobre algum assunto do momento. Geralmente é um espaço claramente denominado numa das primeiras páginas da edição. No caso citado, parece ser a voz de ARS no jornal, pois existia também o editorial nominado como tal, escrito por um dos dirigentes, por vezes, pelo próprio presidente José Matusalém Comelli. Ou seja, naquele momento haviam dois espaços em que a opinião da empresa era expressa. A de "Informação Geral" trazia aspectos dos bastidores da politica e defendia interesses do ex-governador, e a o editorial propriamente dito fazia considerações sobre algum tema em destaque no jornal. 6- PCR foi dirigente de OE nos anos 1970 e assinou coluna de conteúdo político ideológico por quase 50 anos no jornal, defendendo ideais considerados conservadores, ou de “direita”. Em 2001 foi acusado pelo MPF de fazer apologia de discriminação étnica em artigo que se referia à comunidade indígena do Morro dos Cavalos, em Palhoça. Secretário da Comunicação no governo Konder Reis, após o fim de jornal, atuou em empresa da indústria química do Brasil. 
Pelo relato observa-se que a mudança no enfoque jornalístico causava surpresa aos correligionários acostumados a serem protegidos com o silêncio do jornal a respeito de seus procedimentos muitas vezes contrários aos interesses da comunidade. Embora um veículo vinculado a ARENA e em plena ditadura militar, as representações do fazer jornalístico começavam a mudar e continuariam a se alterar, ao longo do tempo, no periódico.

\section{Apesar da ditadura, gran- des reportagens nos anos 1970 e 1980}

Os anos 1970 e 1980 de fato marcaram o auge do jornal, pela diagramação e formato correspondentes ao que se fazia em todo o país e pelas reportagens produzidas na redação. Além de jornalistas formados vindos de outros estados, o jornal contratou em 1971 o colunista Beto

7- Conforme Tancredo (1998), poucos anos antes de assumir o comando do jornal, Comelli havia sido ajudado pelo sogro a se evadir de Florianópolis para fugir da perseguição dos militares, já que fizera parte da UNEUnião Nacional dos Estudantes, entidade extinta pelo regime ditatorial. A militância estudantil de Comelli teria influenciado na decisão do governo militar, em 1977, de não conceder a outorga de canal de televisão para O ESTADO.
Stodieck $^{8}$, que seria um dos ícones do periódico nos anos dourados. A presença de Stodieck e de jornalistas profissionais na redação marcariam o período em que O ESTADO começaria a ser visto como um impresso mais informativo e menos político, numa busca da imparcialidade jornalística, mesmo sendo um jornal defensor do sistema político vigente e de haver censura à imprensa. Além dos investimentos em maquinário, naquele começo dos anos 1970 iniciou-se uma transformação no fazer jornalístico, e a atuação se dava na perspectiva de que jornalismo é um serviço público, que atende ao interesse público e atua como mediador entre a sociedade e os poderes constituídos. Tornou-se o período em que viveu "fase áurea, em termos de tiragem, circulação e prestígio em todo o estado, com importantes jornalistas e colaboradores [...] era uma escola de jornalismo." (PEREIRA, 1992, p. 119). Essa afirmativa é reforçada por outro jornalista reconhecido na cidade:

Em SC, os anos 1970 e 1980 foram os tempos áureos do jornal O ESTADO, de Florianópolis. A redação, desde a velha sede da Felipe Schmi$\mathrm{dt}$, até o prédio moderno - projetado exclusivamente para o jornal - no Saco Grande - reunia nesta época um grupo dos melhores jornalistas do Sul do país. Esse grupo viveu a repressão da ditadura militar e também disse sim à reconstrução democrática, às diretas já, à nova Constituição. (SARDÁ, 2007, p. 73)

Acontecimentos políticos como a Novembrada, em 1979, e tragédias como a queda de um avião da Transbrasil, no distrito de Ratones, em 1980, receberam ampla cobertura jornalística. A manifestação popular em plena ditadura, surpreendendo a até então pacata Florianópolis, mostrou-se em protesto estudantil e de moradores contra o ex-presidente Figueiredo. O episódio, que passou a ser conhecido como Novembrada, coloca Florianópolis nas manchetes nacionais, embora a emissora de TV do grupo RBS, instalada naquele ano na cidade, tivesse deixado de apresentar seu principal noticiário naquela noite para não tratar do assunto e não se indispor com o governo militar, de quem acabara de receber a concessão do canal de $\mathrm{TV}^{9}$. Detalhado no quadro abaixo, o acontecimento ficou conhecido por aquele nome por ter desencadeado uma sequência de manifestações na quadra que circunda a Praça XV, iniciadas 
no dia 30 do mês de novembro, dia da visita.

A Novembrada é como ficou conhecido o episódio ocorrido durante visita a Florianópolis do último general a exercer a presidência da República no período militar (1964-1985). O General João Baptista Figueiredo, junto com autoridades locais como o então governador Jorge Konder Bornhausen, estavam no Palácio Cruz e Souza, sede do governo estadual à época, em frente à Praça XV de Novembro, também conhecida como Praça da Figueira. Apesar das faixas e balões festivos para o "João da conciliação", mote criado pelo governo central para tentar popularizar a imagem do General Presidente, na mão de algumas pessoas, a maioria dos presentes ali aderiu ao protesto contra o regime militar. O general irritou-se com a manifestação (contra a ditadura e a carestia) e fez um gesto considerado obsceno, desencadeando mais revolta. O então presidente sentiu-se ofendido por supostas agressões verbais e desceu à rua para falar com as pessoas. Iniciou-se bate boca, correria e agressões à comitiva presidencial próximo ao Palácio Cruz e Souza e à rua Felipe Schmidt, no trajeto entre o Palácio e o Senadinho, ponto de café famoso à época e onde o Presidente receberia título de associado. Enquanto o Ministro das Minas e Energia, César Cals, levava um tapa no rosto de motorista de táxi revoltado com os constantes aumentos no preço da gasolina, Figueiredo tomou rapidamente seu café e retornou ao aeroporto, encerrando antecipadamente sua visita à cidade. Nos dias seguintes sete estudantes da UFSC (Adolfo Dias, Amilton Alexandre, Geraldo Barbosa, Ligia Giovanella, Marize Lippel, Newton Vasconcelos e Rosangela Koerich de Souza) foram presos e enquadrados na Lei de Segurança Nacional. Vários protestos mobilizaram moradores da cidade exigindo a libertação dos estudantes, o que ocorreu duas semanas depois. Mesmo assim houve julgamento militar em Curitiba, e os estudantes foram absolvidos por um voto de diferença $(3 \times 2)$, por falta de provas.

Quadro 1. Descrição do episódio Novembrada, ocorrido em 1979.
Um dos jornalistas que trabalhou no dia da visita do general conta como acompanhou o processo de divulgação do assunto:

Eu fui escalado pra visita do Figueiredo pra fazer a coisa mais insignificante que era ficar na rua e ver o general passar em revista à tropa que se formava em honra dele. Mas como eu sou um cara com sorte, repórter tem que ter sorte também... Todo o tumulto aconteceu na rua e eu escrevi na época várias laudas. [...] eu olhei assim, na cesta do lixo metade das laudas tava no cesto e o resto das laudas riscadas. Quer dizer, a história saiu, mas pela metade. [...] Foi uma história manca, contada pela metade, mas foi o registro possível. O Comelli justificou que tinha recebido ligações de generais, da Policia Federal e tal. (CAMARGO, depoimento, 2011).

O depoimento é importante por relatar detalhes dos bastidores daquele momento histórico para a política catarinense e nacional. Demonstra também as intervenções que ocorriam sobre os jornais no período militar, quando a censura se dava diretamente sobre as matérias a serem publicadas, muitas vezes impedindo ou recortando o texto final. O partidarismo explícito, embora em declínio, aparece ainda na primeira eleição para governador, em $1982^{10}$, perto do fim do período ditatorial.

Mesmo com a ampliação do foco jornalístico, em abril de 1985, ainda no início da redemocratização do país, a política estava em destaque na capa de O ESTADO: "Aliança Amin e Jaison está praticamente selada", com foto de ambos e a legenda “...coalizão se dará com a ocupação de espaços no governo por peemedebistas que seguem a sua liderança”. A notícia tinha destaque porque os dois políticos haviam tido uma disputa acirrada na eleição de 1982.
8- Irreverente e controverso, Sérgio Roberto Leite Stodieck (Beto), de familia tradicional da capital catarinense, filho do historiador

Henrique Stodieck e de Maria da Graça Leite

Stodieck, começou sua atividade como colunista em julho de 1971 no jornal O ESTADO, aos 25 anos.

Formara-se em Direito na Universidade Federal do Rio de Janeiro e tivera sólida formação intelectual e cultural. Dizia-se um colunista "social/lógico", e procurava mostrar as diferenças da sua coluna em relação ao que se conhecia por colunismo social. Apresentava-se como profissional ético que pretendia dar um significado social ao seu ofício. No penúltimo ano de sua coluna, ele reafirma na nota É verdade: "Não existe mal maior à imprensa do que o jornalista que bajula o poder. Denigre a profissão, empobrece a classe." (OE E, 11 de agosto de 1989) A coluna seria publicada até julho de 1990 , um mês antes de sua morte, em 6 de agosto do mesmo ano. Fonte: Dados compilados pelos autores a partir da verificação dos jornais citados e do ótimo trabalho de Porto e Lago (1999). 
9- Informação verbal destacada pelo jornalista Moacir Pereira em palestra em evento alusivo aos 30 anos da novembrada realizado no auditório do CFH/UFSC dias 29 e 30/11/2009. 10- Conforme Fernandes (1998 p. 87) "no ano do retorno das eleições para o governo do Estado, o posicionamento político do jornal fica explícito em seu apoio a Esperidião Amin", do PDS (ExArena). Aguiar (1991) analisou os editoriais do jornal e constatou que o candidato Amin não teve nenhuma referência desfavorável, enquanto o candidato da oposição, Jaison Barreto, era classificado como "radical" $e$ "despreparado". (p. 238 e 241)
Na mesma capa do jornal, foto legenda com protesto liderado pelo Partido dos Trabalhadores contra aumento da tarifa de ônibus. Além disso, na política local, a manchete: "Empreguismo na prefeitura é denunciado" - Armando Lisboa, suplente de vereador do PMDB que assumira por Aloizio Piazza ter se tornado prefeito, fez a denúncia.

Pode-se observar que além de tentar evidenciar uma postura democrática, o jornal aproveita para "alfinetar" o PMDB, adversário histórico do então PDS. As manchetes em destaque e as notas de coluna indicam como ainda eram presentes no jornal naquele período as questões políticas, os cargos públicos, os interesses partidários. "Governo nega boicote a Florianópolis", e "Cai o nível na Assembléia”, por briga entre peemedebistas, também eram manchetes naquele mês.

O governo estadual era do PDS, sigla afinada com o jornal, e a prefeitura fora recém assumida pelo PMDB. Ao mesmo tempo, alguns dias depois, viase em destaque matéria sobre pobreza em Florianópolis, dizendo que havia "1.500,00 famílias sem casa" e que "Crescem invasões". Em manchete secundária, "Leste da Ilha teme poluição desenfreada". Uma grande reportagem no segundo caderno de um fim de semana tratava do lixo urbano.

Num outro dia do mesmo mês, também no segundo caderno, a manchete: "Florianópolis, um misto de beleza, insalubridade e grandes deficiências". Alguns meses depois, em novembro, reportagens especiais tratam da miséria. O jornal tentava contemplar assuntos de interesse econômico e social embora mantivesse também o espaço para as controvérsias políticas da cidade e do estado.

\section{Um jornal versus um conglomerado: a chegada da RBS muda a imprensa e a cidade}

Uma segunda "invasão" de gaúchos na redação ocorreria em 1985, conforme informação do próprio O ESTADO, em matéria retrospectiva no aniversário de 76 anos. A chegada destes jornalistas coincide com o período de redemocratização do país e a eleição do candidato de oposição, Edson Andrino (PMDB), para prefeito, que teve apoio de setores do PT, inclusive com nomes no secretariado do governo municipal. É um momento de renovação política e cultural na cidade. Além disso, a RBS iniciava a implantação do projeto de instalação de seu jornal, trazendo também profissionais do estado vizinho. São fatores que contribuem, entre outros, para as mudanças em curso que começam a ser mais visíveis na cidade. Talvez se possa dizer que se instalara uma nova onda de transformações, depois daquele ocorrida nos anos 1970 com a chegada da Eletrosul e a consolidação da UFSC. Vigorava, na pequena cidade deentão, uma outra concepção empresarial e comercial. Nessa perspectiva quase ingênua para os atuais padrões concorrenciais, o jornal sequer era visto como um empreendimento comercial ${ }^{11}$. Ou seja, para o jornal O ESTADO, o propósito ainda era de informar/formar os leitores, numa expectativa da imprensa como missão. A empresa concorrente já vem com uma nova perspectiva de negócio ${ }^{12}$ e de jornal, tendo como pressuposto o leitor como consumidor, a lógica do 
jornal feito para dar lucro ${ }^{13}$. Ou seja, enquanto o Diário Catarinense adotava uma perspectiva comercial, da imprensa como meio publicitário, O ESTADO ainda tinha como primazia ser um veículo de informação jornalística, sendo a área comercial uma complementação e não o objetivo principal.

A diferença entre os dois estilos é que a RBS utilizava práticas de gerência corporativas e industriais condicionadas pela racionalidade fordista e pós-fordista de acumulação (FONSECA 2005). Cruz (1994) analisa, a partir do conceito de Indústria Cultural, desenvolvido por Theodor Adorno, as estratégias do grupo RBS para implantar-se em Santa Catarina. Essa autora apresenta detalhes de como a empresa, usando o discurso de ser "apolítica", conseguiu convencer os políticos a avalizarem sua entrada no estado. Segundo ela, Maurício Sirotsky Sobrinho e seu filho Nelson procuraram o governador de Santa Catarina, Antonio Carlos Konder Reis, e pediram para que não vetasse a indicação do grupo para a concessão, caso fosse aprovada em Brasília:

Konder Reis disse que não tinha veto a fazer. Para Nelson Sirotsky, essa postura representou um grande trunfo: tinham obtido em Santa Catarina "a isenção do poder político. Não o apoio, mas a muito difícil isenção." Em Brasília a estratégia foi a mesma, de acordo com Nelson Sirotsky. O argumento da capacidade técnica e profissional foi usado para contrapor às alianças políticas existentes [...] Em termos mais amplos, a escolha de um grupo não partidário em SC parece ter coincidido com a mudança da relação do governo federal com o empresariado, em uma nova aliança, mais adequada aos termos do grande capital, onde os setores "tradicionais" foram sendo afastados do poder pelos "modernos", representados pela grande indústria e pela grande empresa. (CRUZ, 1994, p. 63 e 66).

A análise de Cruz mostra como iniciou uma nova fase da imprensa em Florianópolis e em Santa Catarina, passando a dominar a partir de então o conceito de mercado ${ }^{14}$ da comunicação. Até então, rádios e jornais da cidade eram vistos e atuavam basicamente como integradores da sociedade, numa perspectiva ingênua e artesanal de fazer comunicação. Naquela década de 1970, a Rede Globo se expandiu em todo país, por meio de cadeia de emissoras de TV, numa perspectiva de interiorização do Brasil apoiada pelo regime militar. Conforme Ortiz (1991), ocorreu então a convergência de interesses dos militares, que instalaram a infraestrutura de telecomunicações, e do empresariado nacional: os primeiros queriam unificar consciências, e os donos de TV e outros negócios queriam integração de mercados. Assim como a expansão da Rede Globo levou à decadência as TVs que existiam localmente em São Paulo e Rio de Janeiro, a chegada da RBS, inicialmente com seu sistema de televisão e rádio e posteriormente com jornal impresso, significou o fim do "amadorismo" na comunicação em Florianópolis. Conforme Fernandes (1998, p. 74),

Até o final dos anos 1970 o volume de capital investido no mercado de produção cultural na capital era muito baixo. Nesse período os gastos com publicidade começavam a migrar do rádio e dos jornais para a televisão. Contudo, a televisão ainda não havia desenvolvido formas próprias de gestão de seus espaços publicitários, limitava-se a assimilar as mesmas formas de operação da
11- Em entrevista, o último proprietário do jornal diz explicitamente que o objetivo do jornal era primeiramente político e que não visava lucro, como

era o caso de outras

empresas da família, sendo o bastante que se sustentasse economicamente.

12- Cruz (1994, p. 137)) cita os valores cobrados pela RBS TV para inserção comercial em sua programação de horário nobre, cujo montante se equivale a soma das três outras redes de TV local.

Baseada nos custos operacionais, a empresa teria como meta faturar 30 vezes mais do que as outras emissoras.

13- Segundo Lissoni (2006) “A empresa trata o lucro como condição para a existência da atividade empresarial, onde todo o esforço que, segundo os entrevistados, é feito,

deve convergir para resultados. Ao mesmo tempo, os entrevistados afirmam que a visão de longo prazo tem sido um diferencial competitivo da RBS."

14- Entende-se que mercado denomina negócio, objetivo de lucro monetário como prioridade de atuação. É uma relação de troca de bens materiais ou simbólicos, sendo que na perspectiva do marketing, os vendedores são vistos como constituindo uma indústria e os compradores como o mercado. No mercado

da comunicação, as empresas da área são a indústria e o público é o mercado, os potenciais consumidores dos produtos exibidos pelos 
15- Conforme Lissoni (2006), A RBS conta com 6 jornais, 26 emissoras de rádio, um portal de internet, 2 emissoras locais de televisão, uma gravadora, uma operação voltada para o segmento rural e uma empresa de logística. Possui ainda 18 emissoras de TV afiliadas à Rede Globo - tratase da maior rede regional de $T V d a$ América Latina. [...] possui aproximadamente 5 mil funcionários, com um faturamento que em 2005 chegou à casa de R\$1 bilhão, sendo franqueado como o terceiro maior grupo de mídia do Brasil. (p. 74 -75) Em 2012, somente em Santa Catarina a RBS possui cinco jornais. Diário Catarinense (Florianópolis, 1986) Jornal de Santa Catarina (Blumenau, 1992) A Notícia (Joinville, 2006) Hora de Santa Catarina (Florianópolis, 2006) e Sol Diário (Balneário Camboriú, 2012) além de sete emissoras de TV e mais de uma dezena de emissoras de rádio. publicidade e de relacionamento com os anunciantes utilizadas pelas rádios e pelos jornais locais.

A entrada do grupo gaúcho de comunicação demarca um novo estilo de visão empresarial na cidade, introduzindo a perspectiva do marketing e da publicidade profissional. O modo de produção e de difusão da informação muda e, deste período em diante, o crescimento imobiliário e populacional da cidade se acentua. A concorrência passará a se estabelecer no mercado e não mais majoritariamente no plano da política e da camaradagem. Em Santa Catarina, a RBS tornou-se quase que uma voz única ${ }^{15}$ ao dominar todas as áreas da comunicação, tendo o controle das principais emissoras de rádio e TV, comprado os impressos Jornal de Santa Catarina e A Notícia, e ter contribuído para a falência do jornal O ESTADO. Tudo isso sob o controle de uma só família (Sirotsky) foi considerado monopólio comunicacional pelo Sindicato dos Jornalistas de Santa Catarina que apresentou denúncia ao Ministério Público Federal, em 2006, em processo que foi posteriormente arquivado.

\section{Considerações finais}

Nos jornais, em geral, moderno significa o que está na vanguarda, na moda, o que é atual. Seria a oposição a antigo, a ultrapassado. A própria modernização do jornal O ESTADO, no início dos anos 1970, é um marco do período em que mais se destacou, justamente no momento em que o país vivia sob ditadura militar. Em suas páginas, além de defender as bandeiras do antigo PSD, em diversos períodos, há artigos em favor do moderno e da modernidade na cidade e no próprio jornal. Ao mesmo tempo em que era enaltecida a transformação urbana pela qual a cidade passava, ao substituir gradativamente no centro o casario açoriano por prédios verticalizados, o jornal permitiu a crítica a esse modelo, sendo o principal porta voz o colunista Beto Stodieck, frequentemente lembrado por defender a importância do patrimônio histórico, e tratar com ironia personagens de destaque político e social da cidade.

A contemplação de discursos antagônicos demonstra uma forma de se mostrar um jornal pluralista, ao mesmo tempo em que se preocupava em não se descuidar das questões que eram de interesse do regime autoritário e da legenda ARENA, a qual pertencia o exgovernador Aderbal Ramos da Silva, dono do periódico. Mesmo assim, o jornal deixou de ter prestígio junto às autoridades ligadas ao regime militar, talvez porque o genro de ARS, José Matusalém Comelli, que estava a frente do impresso em seu melhor período, tivera atuação na UNEUnião Nacional dos Estudantes, nos anos 1960. Esse "desgaste" na relação entre o então governador do estado e o jornal propiciaram a chegada e o fortalecimento do grupo RBS a Santa Catarina. Com a chegada do principal concorrente, Diário Catarinense (1986), O ESTADO passou a ser conhecido como "o mais antigo", numa referência à sua quase centenária existência, mas que também já era uma indicativa de ultrapassado, superado. Havia sido preterido pelos militares, que optaram pela RBS desde 1977, numa estratégia a serviço do fortalecimento do capital monopolista em todo o país. Frente a esse novo quadro concorrencial O ESTADO foi perdendo espaço junto ao público, resistindo ainda por 20 anos, até deixar de circular completamente, no começo de 2009. 


\section{Referências bibliográficas}

AGUIAR, Itamar. As eleições de 1982 para governador em Santa Catarina - táticas e estratégias das elites no confronto com as oposições. Dissertação (Mestrado em Sociologia Política) - Centro de Filosofia e Ciências Humanas, Universidade Federal de Santa Catarina, Florianópolis, 1991.

AURAS, Marli. Poder oligárquico catarinense: da guerra dos "fanáticos" do Contestado à “opção pelos pequenos". Tese (Doutorado em Filosofia da educação). Pontifícia Universidade Católica, São Paulo, 1991.

CRUZ, Dulce Maria. A RBS em Santa Catarina: estratégias políticas, econômicas e culturais na conquista do mercado televisivo regional. Dissertação (Mestrado em Sociologia Política) - Centro de Filosofia e Ciências Humanas, Universidade Federal de Santa Catarina. Florianópolis, 1994.

FERNANDES, Cíntia San Martin. Indústria cultural ou esfera pública discursiva: a dinâmica dos meios de comunicação de massa em Florianópolis. Dissertação (Mestrado em Sociologia Política) - Centro de Filosofia e Ciências Humanas, Universidade Federal de Santa Catarina, Florianópolis, 1998.

LENZI, Carlos Alberto. Partidos e políticos de Santa Catarina. Florianópolis: Editora da UFSC, 1983;

LISSONI, Juliano. Análise da relação entre família, empresa e propriedade ao longo do ciclo de vida do grupo RBS. Dissertação (Mestrado em Administração) - Centro Sócio Econômico, Universidade Federal de Santa Catarina, Florianópolis, 2006. MATA, Maria Margarete Sell da. Jornal O ESTADO: uma história em construção. (1915-1931) Dissertação (Mestrado em História) - Centro de Filosofia e Ciências Humanas, Universidade Federal de Santa Catarina, Florianópolis, 1996.

MAY, Patrícia Zumblick Santos. Redes político-empresariais de Santa Catarina (1961 - 1970). Dissertação (Mestrado em História) - Centro de Filosofia e Ciências Humanas, Universidade Federal de Santa Catarina, Florianópolis, 1998.

ORTIZ, Renato. A moderna tradição brasileira: cultura brasileira e indústria cultural. São Paulo: Brasiliense, 1991.

PEREIRA, Moacir. Aderbal Ramos da Silva. Florianópolis: Insular, 2011.

PEREIRA, Moacir. Imprensa e Poder. Florianópolis, Lunardelli, 1992.

PERTILE, Ana Maria. Repressão e oposição Política em Santa Catarina: 1964-

1973. Dissertação (Mestrado em História) Programa de Pós Graduação em História, Universidade de Passo Fundo, Passo Fundo/RS, 2003.

PORTO, Bea; LAGO, Fernanda. É tudo mentira. A história segundo Beto Stodieck. Florianópolis: Verde Água Produções Culturais, 1999. RÜDIGER, Francisco. Elementos para a crítica do jornalismo moderno: conhecimento comum e indústria cultural. Revista FAMECOS, Porto Alegre, v.17 n. 3, p. 216-227, set./dez. 2010. Disponível em: < http://revistaseletronicas.pucrs.br/ojs/ index.php/revistafamecos/issue/archive $>$. Acesso em 28 ago., 2012.

SARDÁ, Laudelino (Org.). Da Olivetti à Internet. Tubarão: Unisul, 2007. 
TANCREDO, Luiz Henrique. Doutor Deba, poder e generosidade. Florianópolis: Insular, 1998.

VALENTE, Cesar. A imprensa na Grande Florianópolis. In: BALDESSAR, Maria José \& CRISTOFOLETTI, Rogério (Org.) Jornalismo em perspectiva. Florianópolis: UFSC/Sindjor, 2005. p. 71-84

\section{Jornais}

O ESTADO, Florianópolis. Edições dos meses de abril, maio e novembro de 1985.

O ESTADO, Florianópolis. Edições de maio de 1986 a 2007.

O ESTADO, Florianópolis. Especial 70 anos, maio de 1985.

O ESTADO, Florianópolis. Caderno comemorativo dos 76 anos, 12 maio de 1991.

\section{Entrevistas}

CAMARGO, Jurandir Pires de. Depoimento em entrevista concedida autora.

Gravada em meio digital em 12.08.2011, 13 p.

COMELLI, José Matusalem de Carvalho. Depoimento em entrevista concedida a autora. Gravada em meio digital em 01.09.2011, 19 p.

SCHLINDWEIN, Osmar. Depoimento em entrevista concedida a autora. Gravada em meio digital em 24/10/2011, 13 p.

Este artigo e todo o conteúdo da Estudos em Jornalismo e Mídia estão

disponíveis em https://periodicos.ufsc.br/index.php/jornalismo

Estudos em Jornalismo e Mídia está sob a Licença Creative Commons 2.5 